\title{
Origin of Ceratocystis platani on Native Platanus orientalis in Greece and Its Impact on Natural Forests
}

\author{
Roberto G. Ocasio-Morales, Department of Plant Pathology, Iowa State University, Ames 50011; Panaghiotis \\ Tsopelas, NAGREF-Institute of Mediterranean Forest Ecosystems Terma Alkmanos, 11528 Athens, B. O. 14180, \\ Greece; and Thomas C. Harrington, Department of Plant Pathology, Iowa State University, Ames
}

\begin{abstract}
Ocasio-Morales, R. G., Tsopelas, P., and Harrington, T. C. 2007. Origin of Ceratocystis platani on native Platanus orientalis in Greece and its impact on natural forests. Plant Dis. 91:901-904.

Canker stain of plane tree recently was reported in a small area of southwestern Greece on natural populations of the important riparian species, oriental plane tree, Platanus orientalis. The fungus Ceratocystis platani $(=C$. fimbriata f. platani) was successfully isolated from infected, stained wood of 15 dead or dying trees on the Peloponnese Peninsula. Genetic analyses of these 15 isolates from Greece, using nuclear and mitochondrial DNA fingerprints, showed the fungus to be identical to the genotype reported from Italy, France, and Switzerland. A polymerase chain reaction-based microsatellite analysis of eight polymorphic loci discovered a new microsatellite allele in one of the isolates from Greece, but this may be due to a mutation after introduction of a single strain. Earlier studies indicated that the most common European genotype had been introduced from eastern North America to Italy during World War II. The recent introduction to Greece appears to have originated from Italy, France, or Switzerland, rather than from eastern North America, where the fungus is native. The pathogen is having a dramatic impact on the natural population of $P$. orientalis in southwestern Greece, and containment measures should be imposed before it spreads throughout the natural range of this ecologically and historically important host.
\end{abstract}

Canker stain of plane tree, caused by the fungus Ceratocystis platani (J. M. Walter) Engelbr. \& T. C. Harr. (三Endoconidiophora fimbriata f. platani) (6), is a serious disease that attacks Platanus spp. in the United States and Europe $(1,4,7,18)$. The pathogen is usually found in urban areas on London plane (Platanus acerifolia), a hybrid of American sycamore (P. occidentals) and oriental plane ( $P$. orientalis), in the United States and Europe $(18,20,29)$, as well as in commercial plantations of American sycamore in the United States (16). The disease causes staining of the xylem, disruption of water movement, cankers, and usually death of the tree (4).

Previous genetic studies have shown that there is variation in populations of $C$. platani in the southeastern United States, where the fungus is believed to be native (7). The genetic data (7) also suggest that there were at least two separate introductions of the pathogen: one to Modesto, CA

Corresponding author: T. C. Harrington

E-mail: tcharrin@iastate.edu

Accepted for publication 2 February 2007

doi:10.1094/PDIS-91-7-0901

(C) 2007 The American Phytopathological Society
(20) and the other to Europe (18). In Europe, the fungus was first seen shortly after World War II in Naples, Italy, from where it apparently spread throughout Italy to southeastern France and Switzerland (18). It has been suggested that $C$. platani was introduced to Naples on crating material for military supplies during World War II (18), perhaps from the Philadelphia area, where there was an epidemic on ornamental $P$. acerifolia during the 1930 s and 1940s (7).

The disease was first observed in Greece in the fall of 2003 on oriental plane in the Messinia Prefecture of southwestern Peloponnese (26), where $C$. platani has caused substantial mortality of oriental plane in natural stands along streams and rivers, as well as in ornamental plantings of oriental plane and London plane (27). Oriental plane is an important riparian species (22) that occurs naturally from southeastern Europe to southwest Asia (2), and the new epidemic is near the southwestern extreme of the natural distribution of oriental plane. Oriental plane is considered highly susceptible to canker stain, American sycamore is relatively resistant, and London plane is generally intermediate in resistance $(18,28)$. The appearance of the disease in the natural range of oriental plane is alarming, and containment or eradication mea- sures may be warranted if the introduction has been recent and the distribution of the pathogen in Greece is limited.

We wanted to assess the epidemic in Greece and determine if the population of C. platani there was introduced from Europe or North America. We used nuclear and mitochondrial fingerprinting and polymerase chain reaction (PCR)-based microsatellite markers to test the hypothesis that the Greek population of $C$. platani was introduced from elsewhere in Europe. We also report observations of the disease in Greece, including associations with insects that may facilitate pathogen spread.

\section{MATERIALS AND METHODS}

Disease detection and fungal isolation. Dead and dying plane trees were examined in spring 2004 through fall 2005 in natural stands along streams and rivers in an area of about $400 \mathrm{~km}^{2}$ in Messinia Prefecture of southwestern Greece. Sites with dead and dying trees were identified through consultation with local forestry officials, and trees with symptoms of canker stain were found at 10 riparian sites. Some of the sites appeared to be newly infested areas, but the disease appeared to have been present for several years at several sites. Symptomatic plane trees in villages also were examined. Three to five recently killed or dying trees were examined at each site.

The disease was confirmed in dead and dying trees by removing the bark from infected roots, stems, or branches with an axe to reveal the discolored, infected wood. Other trees were felled, and cross sections of the stem with discolored sapwood were removed for isolation attempts. Cores were taken from the edge of lesions of some living trees with a sterilized increment borer, cut into discs 4 to $5 \mathrm{~mm}$ thick, placed into petri dishes with moistened filter paper, and incubated for 6 to 8 days at 23 to $24^{\circ} \mathrm{C}$. The discs then were checked under a dissecting microscope $(50 \times$ magnification) for the presence of perithecia with ascospore masses at the tip. Ascospores from the tip of the perithecial neck were transferred with a sterilized needle to petri dishes with $2 \%$ malt extract agar (MEA).

Ambrosia beetle frass. Copious amounts of insect frass associated with 
attacks by woodboring ambrosia beetles (Coleoptera: Curculionidae, subfamily Platypodinae) were seen on the trunk of many of the dead and dying oriental plane. Adults of the ambrosial beetle species Platypus cylindrus F. were excavated from galleries in the wood of two trees.

We collected ambrosia beetle frass that had been expelled from three diseased trees. The frass was collected in plastic sterile vials and the carrot disc method (17) was used to isolate $C$. platani by placing a small quantity of frass between two slices $(5 \mathrm{~mm}$ thick) of carrot. The carrot "sandwiches" were placed into plastic petri dishes with moistened filter paper and incubated for 1 week at 23 to $24^{\circ} \mathrm{C}$. The carrot discs were examined under a dissecting microscope for the presence of perithecia and ascospores, and the fungus was isolated from the ascospore masses as described above.

DNA extraction. Genetic markers of 15 isolates from Greece; an isolate from Florence, Italy; and an isolate from Avignon, France were compared with those of the $C$. platani isolates that had been studied earlier (7). The 17 new isolates were grown on malt yeast extract agar (MYEA; 2\% malt extract, $0.2 \%$ yeast extract, and $2 \%$ agar) for 7 days for conidial production. Plates were flooded with $10 \mathrm{ml}$ of sterile water, and conidia, conidiophores, and mycelium were scraped from the plates and placed in $500 \mathrm{ml}$ of broth medium $(2 \%$ malt extract and $1 \%$ yeast extract in 2-liter flasks). The flasks were incubated at room temperature with shaking for 24 to $48 \mathrm{~h}$. Genomic DNA was extracted from the germlings following the method of DeScenzo and Harrington (5).

Nuclear DNA fingerprinting. A total of $15 \mu \mathrm{g}$ of extracted DNA was restricted with PstI following the procedure of Engelbrecht et al. (7). The digested DNA was electrophoresed for $20 \mathrm{~h}$ at $80 \mathrm{~V}$ on a $1.2 \%$ agarose gel $(19.5$ by $25.5 \mathrm{~cm}$ ) (BioRad Certified Molecular Biology agarose, Bio-Rad). Gels were dried, hybridized with the ${ }^{32} \mathrm{P}$-labeled $(\mathrm{CAT})_{5}$ oligonucleotide, and washed (5). Hybridized gels were exposed to a phosphor screen (Molecular Dynamics) for 7 days.

Mitochondrial DNA fingerprinting. Approximately $30 \mu \mathrm{g}$ of total genomic DNA was restricted using HaeIII, which selectively digests GC-rich nuclear DNA and leaves relatively large fragments of multicopy, AT-rich mitochondrial DNA (30). The restriction products were electrophoresed as described above. Lambda DNA/HindIII marker (Promega) was used as the standard on the outer lanes. Gels were stained with ethidium bromide for 30 min and visualized with ultraviolet (UV) light.

Microsatellite analysis. Alleles (bands of differing size) from 8 of 16 polymorphic, PCR-based microsatellite markers (23) were generated and compared with those from the earlier study (7). Only eight loci were used because those were the ones that showed polymorphism within the North American population of $C$. platani. For each primer pair, one of the primers was fluorescently labeled. The PCR products were electrophoresed using a fourcapillary ABI Prism 3100-Avant Genetic Analyzer (Applied Biosystems Inc.). Earlier studies $(7,23)$ used polyacrylamide gel electrophoresis, and there were some differences in the band sizes $( \pm 1 \mathrm{bp})$ with some of the alleles using the capillary system. All reported allele designations (approximate product size in base pairs) correspond to the allele names given in the earlier studies $(7,23)$.

Genetic relationships among the isolates of $C$. platani from Greece and the isolates from the United States and Europe were determined with the microsatellite alleles using the unweighted pairgroup method with arithmetic means (UPGMA) algorithm in PAUP (24).

\section{RESULTS}

Disease occurrence and symptoms. The most obvious symptom of the disease on oriental plane was the sudden death of a portion of the crown. A branch or the entire tree may have failed to produce leaves in the spring, or the emerging leaves suddenly withered and died. In most of the diseased trees, the outer bark of the trunk was thick and roughened, so cankers were not evident without cutting through the bark and observing necrosis in the inner bark and the bluish-black to reddish-brown discoloration of the sapwood. Also, most infections of streamside trees appeared to occur through the roots, and stem cankers were not evident. In cross section, the stained sectors in the outer sapwood rings often were lens shaped, and the discoloration tapered toward the center of the stem. Successful isolations of $C$. platani were made from stained wood of 1 London plane and 14 oriental planes at 13 localities.

Canker stain of oriental plane appeared to be confined to a region of approximately $400 \mathrm{~km}^{2}$ in Messinia Prefecture (latitudes $37^{\circ}$ to $37^{\circ} 30^{\prime}$ ), in the southwestern region of the Penolopennese Peninsula, southwest of Athens. Ornamental plane trees of different ages and sizes in residential areas and recreational sites apparently have died from infection; some of the dead trees were large and centuries old. However, the impact has been greater in natural stands. Hundreds of dead and dying oriental planes were found along streams and rivers, where it appeared that the pathogen had spread tree-to-tree through root contact or through running water. Patches of up to 15 to 20 dead and dying trees were often evident along streams. Examination of root systems suggested that some of the spread to adjacent trees was through root grafting. Also, dead logs and pieces of branches from killed trees were observed to be carried by water downstream, and such infested material may serve as an important source of inoculum.

Some newly infected trees were observed that had been wounded by cutting tools during road maintenance, and infection appeared to have taken place through these pruning wounds, probably from contaminated saws. The northern-most focus of infection was along a highway where overhanging branches had been cut, and the cut surfaces were heavily colonized by the fungus. In a few cases, it appeared that the pathogen had spread into new areas with excavation machinery, and infections may have originated in wounded roots.

Many of the recently dead and dying oriental planes were found infested by wood-boring ambrosia beetles, and attacking adults of $P$. cylindrus $\mathrm{F}$. were identified from two trees. Excavated frass on the outer bark was collected from three trees, and $C$. platani was successfully isolated from the frass collected from two of these trees.

Nuclear DNA fingerprinting. A total of 17 scorable $(\mathrm{CAT})_{5}$ bands resulted from

Table 1. Microsatellite alleles found in the United States and European populations of Ceratocystis platani ${ }^{\text {a }}$

\begin{tabular}{lcccccc}
\hline Locus & Eastern United States $(\boldsymbol{n}=\mathbf{3 3})$ & California $(\boldsymbol{n = 6})$ & Italy $(\boldsymbol{n = 2 6})$ & Switzerland $(\boldsymbol{n}=\mathbf{1})$ & France $(\boldsymbol{n}=\mathbf{2})$ & Greece $(\boldsymbol{n}=\mathbf{1 5})$ \\
\hline CAA9 & $270,312,368,386,400,410$ & 276 & 294 & 294 & 294 & 294 \\
CAA15 & 288,317 & 317 & 317 & 317 & 317 & 317 \\
CAA38 & 134,157 & 134 & 157 & 157 & 157 & 157 \\
CAA80 & $268,294,300$ & 291,297 & 300 & 340 & 300 & 300 \\
CAG15 & $317,333,337,359,365$ & $329,346,353$ & 340,343 & 326 & 340 & 340 \\
CAT3K & $323,326,329$ & 391 & 394 & 394 & 394 \\
CAT1200 & 391,409 & 295 & 290 & 394 \\
GACA650 & $235,256,259,276,300,328$ & 295 & 290 & 290,319 \\
\hline
\end{tabular}

a All data on isolates from eastern United States, California, Italy, Switzerland, and France are from Engelbrecht et al. (2004), except for new data on one isolate from Italy and one isolate from France; $n=$ number of isolates tested. 
the PstI nuclear DNA restriction of the 15 isolates from Greece and the new isolate from Italy. The nuclear fingerprinting band pattern of the 15 isolates from Greece and the new Italian isolate was identical to that of the other isolates from Europe (7).

Mitochondrial DNA fingerprinting. The mitochondrial DNA fingerprint pattern of the 15 isolates from Greece was identical to that of the isolates from the Italian, French, and Swiss populations of C. platani (7). In all, 27 scorable bands were found in the U.S. populations based on the previous study (7), and 17 of these bands were polymorphic. The Greek isolates had 19 scorable bands, the same bands found in the European population (7).

Microsatellite analysis. For the eight polymorphic microsatellite markers, 14 of the 15 Greek isolates of $C$. platani, a new isolate from Italy, and a new isolate from Avignon, France had the same microsatellite alleles as the most common genotype from Italy, France, and Switzerland. Alleles for each locus for the $C$. platani isolates from Greece as well as for the isolates previously studied (7) are shown in Table 1. One isolate from the Greek population, isolate $\mathrm{C} 2177$, had a unique allele at locus GACA650. The allele was not found in the U.S. population studied earlier (7).

Using the microsatellite markers, the Greek isolates of $C$. platani were placed together with the other isolates from Europe using UPGMA (Fig. 1).

\section{DISCUSSION}

The isolates of $C$. platani from Greece proved to be identical to the isolates collected in other regions in Europe based on both $(\mathrm{CAT})_{5}$ nuclear and HaeIII mitochondrial fingerprinting. In addition to the 25 isolates from Italy used in the previous study (7), we analyzed a new isolate from Florence, Italy that proved to be the same genotype as the other European isolates.

A new microsatellite allele was found in one $C$. platani isolate from Greece. The PCR product for locus GACA650 was of a larger size $(319 \mathrm{bp})$ than the product found in other European isolates. Microsatellite regions are prone to mutations because of the numerous, tandemly repeated sequences (9). This hypervariability could be an explanation for the presence of this new allele in the Greek population. Two unique alleles were found earlier in isolates from Italy, and those were thought to be the result of mutations after the introduction of a single genotype into Naples (7).

Aside from possible mutations at three microsatellite loci, the European population of $C$. platani is a single clone, and it appears that a single genotype of $C$. platani was introduced to Europe (7). Most Ceratocystis spp. have a sexual state but, like many Ceratocystis spp., C. platani can self via unidirectional mating type switching $(10,31)$. Selfing is likely more common than outcrossing in such Ceratocystis spp.
(11) and, thus, the genotype of a single, introduced strain could be maintained clonally.

The population in Italy, France, and Switzerland is thought to be the result of a single introduction of the pathogen through Italy during World War II $(7,18)$. The Greek population likely is derived from this Italian introduction. One possibility is that the source for the Greek introduction was infected rooted-cuttings from Italy. Movement of such nursery stock is common among European Union countries, and London plane is produced and shipped from Italy (19), where canker stain is widespread. However, we cannot rule out the possibility that the fungus was introduced on wood used for packaging, the probable pathway of the fungus from the United States to Italy $(7,18)$.

Ambrosia beetle attacks were common on most of the dead and dying oriental planes in Greece. The two adult beetles that we excavated from the wood of diseased trees were identified as Platypus cylindricus. C. platani was isolated from the frass emanating from the galleries on two separate trees. The frass from ambro-

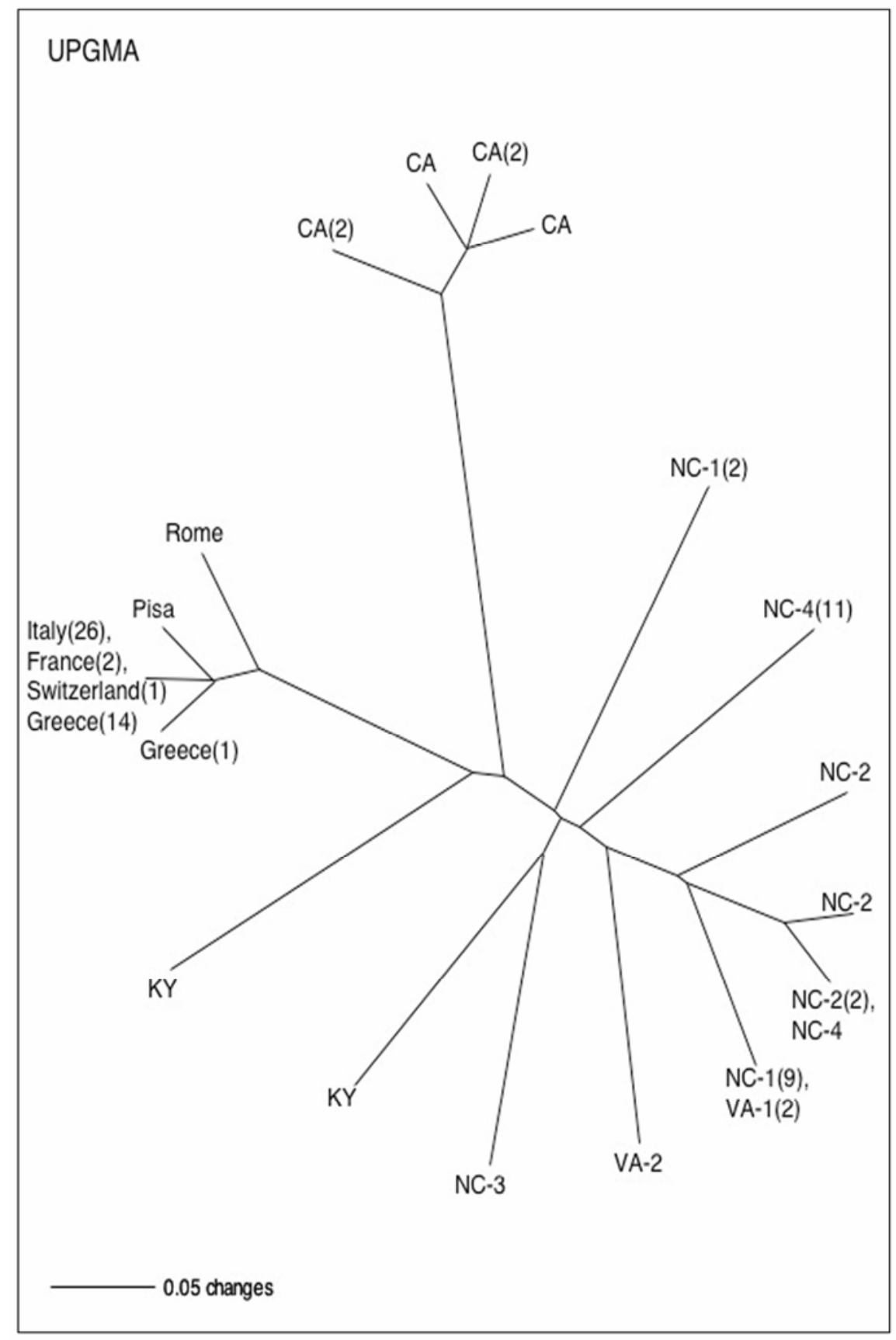

Fig. 1. Dendrogram of the unweighted pairgroup method with arithmetic means (UPGMA) analysis of microsatellite alleles found in populations of Ceratocystis platani. The two-letter abbreviations indicate the state $(\mathrm{CA}=$ California, $\mathrm{KY}=$ Kentucky, $\mathrm{VA}=$ Virginia, and $\mathrm{NC}=$ North Carolina $)$ from which the isolates were collected. The numbers in parentheses are the number of isolates with that unique genotype (combination of microsatellite alleles). 
sia beetles is known to contain viable propagules of other Ceratocystis spp. (13), and aerially dispersed frass is infectious. This is known to be a mechanism of dispersal of other members of the Latin American clade of $C$. fimbriata, specifically $C$. cacaofunesta (12) and $C$. fimbriata sensu stricto (21). Ambrosia beetle attacks on diseased plane trees have not been noted in European countries outside the natural range of oriental plane; therefore, the association with ambrosia beetles in Greece suggests that the pathogen will spread more quickly there than it has in Italy, France, and Switzerland.

Movement of $C$. platani through water is an important dispersal factor in France, Switzerland, and Italy (8). Because Plata$n u s$ orientalis is a riparian species, the pathogen may be able to spread quickly along water courses (27). Movement of the pathogen in water, especially as infested ambrosia beetle frass, as well as aerial dispersal in beetle frass, may lead to rapid spread throughout the natural range of $P$. orientalis.

The introduction of $C$. platani to Greece is expected to have a dramatic impact on riparian forests of the region. Along stream and river courses where the disease is present, stretches of streams of up $100 \mathrm{~m}$ have no surviving plane trees. The pathogen was noted on $P$. orientalis along waterways in Sicily (18), where it is believed the tree has naturalized. However, the disease is now on wild $P$. orientalis along river courses in Greece, and the pathogen appears capable of rapid spread throughout the natural range of the host (2). As the pathogen spreads, forest composition may change dramatically because $P$. orientalis is highly susceptible to canker stain, much more so than American sycamore and London plane (28), and few or no trees may escape. If we account for the rapid spread of the fungus in water, this riparian species could be driven quickly to extinction.

The ecological impact of the disease in the natural range of $P$. orientalis could be comparable to the damage caused to other forest ecosystems in North America and Europe by exotic pathogens such as those that cause chestnut blight, Dutch elm disease, and white pine blister rust $(3,14,15,25)$. In each of these cases, there was limited resistance in the native host population to an exotic pathogen from another continent. In contrast to these other introductions, where the pathogens were well established and widespread before they were recognized, the introduction of $C$. platani to Greece has been recent, and the geographic extent of the infestation is relatively limited. Aside from human spread or dispersal in running water, propagules of the canker stain pathogen probably are spread only short dis- tances. The restriction of the new infestation to a peninsula, as well as the fact that natural oriental plane trees are mostly confined to waterways, would make it possible to contain the infestation or at least slow down its spread. Protection of natural populations of $P$. orientalis will require aggressive sanitation and eradication programs in Messinia Prefecture, but action will need to be taken soon.

\section{ACKNOWLEDGMENTS}

We thank A. Vigouroux for providing helpful insights, F. Maire for providing an isolate, and A. Angelopoulos and N. Soulioti for their assistance. Supported by NSF DEB-0128104.

\section{LITERATURE CITED}

1. Baker, C. J., Harrington, T. C., Krauss, U., and Alfenas, A. C. 2003. Genetic variability and host specialization in the Latin American clade of Ceratocystis fimbriata. Phytopathology 93:1274-1284.

2. Besnard, G., Tagmaount, A., Baradat, P., Vigouroux, A., and Bervillé, A. 2002. Molecular approach of genetic affinities between wild and ornamental Platanus. Euphytica 126:401412.

3. Brasier, C. M., and Kirk, S. A. 2001. Designation of the EAN and NAN races of Ophiostoma novo-ulmi as subspecies. Mycol. Res. 105:547-554.

4. CAB International. 2001. Ceratocystis fimbriata (original text prepared by C. J. Baker and T. C. Harrington). In: Crop Protection Compendium. CAB International, Wallingford, UK.

5. DeScenzo, R. A., and Harrington, T. C. 1994. Use of $(\mathrm{CAT})_{5}$ as a DNA fingerprinting probe for fungi. Phytopathology 84:534-540.

6. Engelbrecht, C. J. B., and Harrington T. C. 2005. Intersterility, morphology and taxonomy of Ceratocystis fimbriata on sweet potato, cacao and sycamore. Mycologia 97:57-69.

7. Engelbrecht, C. J. B., Harrington, T. C., Steimel, J., and Capretti P. 2004. Genetic variation in eastern North American and putatively introduced populations of Ceratocystis fimbriata f. platani. Mol. Ecol. 13:29953005.

8. Grosclaude, C., Olivier, R., Pizzuto, J. C., and Romiti, C. 1991. Etude experimentale du transport de I'inoculum de Ceratocystis fimbriata f. platani par I'eau d'une riviere. Eur. J. For. Pathol. 21:168-171.

9. Hancock, J. M. 1999. Microsatellites and other simple sequences: genomic context and mutational mechanisms. Pages 1-9 in: Microsatellites: Evolution and Applications. D. B. Goldstein and C. Schlötterer, eds. Oxford University Press.

10. Harrington, T. C., and McNew, D. L. 1997. Self-fertility and uni-directional mating type switching in Ceratocystis coerulescens, a filamentous ascomycete. Curr. Genet. 32:52-59.

11. Harrington, T. C., Steimel, J., and Kile, G. A. 1998. Genetic variation in three Ceratocystis species with outcrossing, selfing and asexual reproductive strategies. Eur. J. For. Pathol. 28:217-226.

12. Iton. E. F. 1960. Studies on a wilt disease of cacao at River Estate. II. Some aspects of wind transmission. Pages 47-58 in: Annual Report on Cacao Research, 1959-60. Imperial College of Tropical Agriculture, University of West Indies, St. Augustine, Trinidad.

13. Kile, G. A. 1993. Plant diseases caused by species of Ceratocystis sensu stricto and Chalara. Pages 173-183 in: Ceratocystis and
Ophiostoma: Taxonomy, Ecology and Pathogenicity. M. J. Wingfield. K. A. Siefert, and J. F. Webber, eds. American Phytopathological Society Press, St. Paul, MN

14. Maloy, O. C. 2001. White Pine Blister Rust. Plant Health Progress. Online, doi:10.1094/ PHP-2001-0924-01-HM.

15. McCarroll, D. R., and Thor, E. 1985. Pectolytic, cellulytic and proteolyc activities expressed by cultures of Endothia parasitica, and inhibition of these activities by components extracted from Chinese and American chestnut inner bark. Physiol. Plant Pathol. 26:367-378.

16. McCracken, F. I., and Burkhardt, E. C. 1977. Destruction of sycamore by canker stain in the midsouth. Plant Dis. Rep. 61:984-986.

17. Moller, W. J., and De Vay, J. E. 1968. Carrot as a species-selective isolation medium for Ceratocystis fimbriata. Phytopathology 58:123-124.

18. Panconesi, A. 1999. Canker stain of plane tree: a serious danger to urban plantings in Europe. J. Plant Pathol. 81:3-15

19. Panetsos, K. P.1990. Breeding of the genus Platanus in Greece. Sci. Ann. Dep. For. Aristotelian Univ. Thessaloniki, Greece. LC/2:37-53.

20. Perry, E., and McCain, A. H. 1998. Incidence and management of canker stain in London plane trees in Modesto, California. J. Arboric. 14:18-19

21. Rossetto, C. J., and de Medeiros, J. W. A. 1967. Seca da mangueira. II. Existencia do complexo, artropodos do solo Ceratocystis fimbriata Scolytidae, no estado de Sao Paulo. Rev. Soc. Bras. Fitopatol. 1:19-32.

22. Schnitzler, A., Hale, B. W., and Alsum, E. 2005. Biodiversity of floodplain forests in Europe and eastern North America: a comparative study of the Rhine and Mississippi Valleys. Biodivers. Conserv. 14:97-117.

23. Steimel, J., Engelbrecht C. J. B., and Harrington, T. C. 2004. Development and characterization of microsatellite markers for the fungus Ceratocystis fimbriata. Mol. Ecol. Notes 4:215-218

24. Swofford, D. L. 2003. PAUP*: Phylogenetic Analysis Using Parsimony (* and other methods), version 4.0b 10. Sinauer Associates, Sunderland, MA

25. Thor, E. 1978. Breeding of American chestnut. Pages 7-10 in: Proc. Am. Chestnut Symp. W. L. MacDonald, F. C. Cech, J. Luchok, and H. C. Smith, eds. West Virginia University Books, Morgantown.

26. Tsopelas, P., and Angelopoulos, A. 2004. First report of canker stain disease on plane trees, caused by Ceratocystis fimbriata f. sp. platani in Greece. Plant Pathol. 53:531.

27. Tsopelas, P., Harrington, T. C., Angelopoulos, A., and Soulioti, N. 2006. Canker stain disease of oriental plane in Greece. Pages 55-57 in: Proc. 12th Congr. Mediterr. Phytopathol. Union. E. Tjamos and E. Paplomatas, eds. Rhodes Island, Greece.

28. Vigoroux, A., and Olivier, R. 2004. Firs hybrid plane trees to show resistance against canker stain (Ceratocystis fimbriata f. sp. platani). For. Pathol. 34:307-319.

29. Walter, J. M., Rex, E. G., and Schreiber, R. 1952. The rate of progress and destructiveness of canker stain of plane-trees. Phytopathology 42:236-239

30. Wingfield, B. D., Harrington, T. C., and Steimel, J. 1996. A simple method for detection of mitochondrial DNA polymorphisms. Fungal Genet. Newsl. 43:56-60.

31. Witthuhn, R. C., Harrington, T. C., Wingfield, B. D., Steimel, J., and Wingfield. M. J. 2000 Deletion of the MAT-2 mating type gene during uni-directional mating type switching in Ceratocystis. Curr. Genet. 38:48-52. 